UDC 332.2:528.9:004.01

\title{
BASIC REQUIREMENTS FOR SOFTWARE DEVELOPMENT OF AN AUTOMATED LAND MONITORING SYSTEM
}

Ibatullin Sh.I., Doctor of Economics Sciences, professor, member of the National Academy of Agrarian Sciences of Ukraine, Land Management Institute of the National Academy of Agrarian Sciences of Ukraine e-mail: shamilibatullin@gmail.com

Dorosh O.S., Doctor of Economics Sciences, professor, National University of Life and Environmental Sciences of Ukraine e-mail:dorosholgas@ukr.net

Tarnopolskyi A.V., Land Management Institute of the National Academy of Agrarian Sciences of Ukraine e-mail: landukrainenaas@gmail.com

Abstract. The main requirements for the land monitoring system are identified, including requirements for its functionality, information support, visualization of spatial information, interactive maps, database structure, general architecture, analytical criteria and other types of support.

The main directions of land monitoring, within which the automated system should function, in particular, monitoring of civil law transactions in terms of territories, forms of ownership, land categories; monitoring of price dynamics; monitoring the condition of lands by their quantitative and qualitative characteristics; assessment and forecasting of land transformation.

Substantiated requirements for the subsystems of administration, ergonomics, infrastructure, ensuring the turnover of change, geodetic and mathematical basis, etc.

Emphasis is placed on the need to ensure the protection of information, including confidential information, as the land monitoring system should contain not only information on the objects of monitoring, but also information on the subjects of land relations, whose rights should be guaranteed. 
The need to use directories and classifiers, in particular the classification of administrative-territorial entities of Ukraine, types of economic activity, as well as integration with various state official registers as part of the national geospatial data infrastructure platform is taken into account.

Keywords: software, land monitoring, database, land resources, automated information and communication systems, geospatial data infrastructure, land cadastre.

Actuality. Solving the problems of land monitoring and soil quality control at the current stage of information technology development and accelerating operational management decisions in the run-up to the introduction of the agricultural land market is impossible without the development and implementation of a new type of software.

The requirements for such land monitoring software are non-standard, they are designed to ensure harmonization of different types and kinds of data.

Characterizing the requirements for the software of the automated information system of land monitoring and soil quality control (hereinafter - AIS) in general, we note that the latter is aimed at providing public administration and local government systematic, reliable, operational information on land status and assessment of their change.

The software should guarantee the creation of a tool for information support of organizational and management processes, effective management and use of information resources on the circulation of agricultural land.

The above non-standard requirements for software determine the relevance of research in this area.

The aim of the study is to systematize the requirements for the software of the automated information system of land monitoring, aimed at the integration of different types and kinds of data for the implementation of a wide range of analytical tasks.

Results of the study. Within the framework of software development, the issues of studying the state of land use efficiency, changing the legal status and 
ensuring control over compliance with the legal regime of land use, land use in ways that can lead to land degradation, soil quality control, timely decision-making to prevent loss should be addressed. soil fertility, study and evaluation of land turnover processes, their indicators (transactions and market conditions).

Based on the integration with the data of the State Land Cadastre, the State Register of Real Property Rights and other state registers, the software is developed as a web platform, the modules of which should be built on the principles of scaling the functionality of the system in the future (Fig. 1) [1].

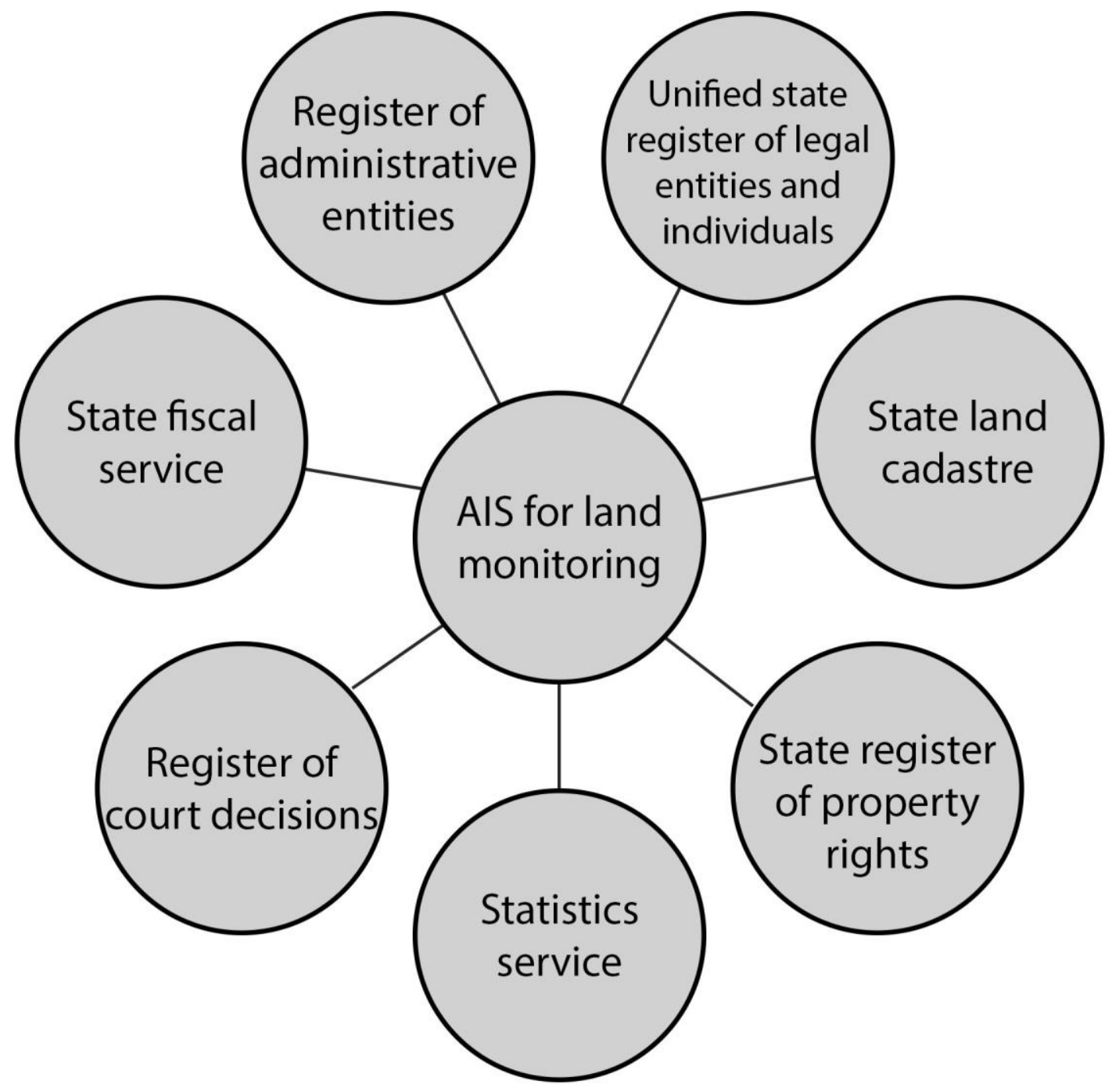

Fig. 1. The structure of bodies and services - participants in information interaction in the monitoring of land.

AIS software is developed in the form of modules in order to: 
- ensuring the initial collection and primary processing of source information required for the preparation of reports on certain criteria for monitoring land transactions, land status and their changes;

- creation of a unified reporting system for certain indicators of monitoring of land transactions, land status and their changes;

- improving the quality (completeness, accuracy, reliability, timeliness, consistency) of information on the state of lands and their changes;

- ensuring control over compliance with certain norms and rules on land transactions, land conditions and their changes;

- ensuring the visualization of spatial data for certain thematic analytical groups;

- providing technological processes for updating data on certain thematic analytical groups;

- providing scientific, technical-economic and information-analytical substantiations of administrative decisions of state authorities and local selfgovernment bodies;

- ensuring regulated access to AIS databases in accordance with the status of users (including unauthorized).

- As a result of AIS software development, digital business processes will be created to improve the value of the following indicators:

- time of collection and processing of primary source information;

- the number of information systems used to prepare analytical information;

- time spent on information and analytical activities [2].

Requirements for the development of software for an automated land monitoring system should take into account the requirements of the following laws and regulations: the Land Code of Ukraine; Laws of Ukraine "On the State Land Cadastre", "On Information”, “On Electronic Documents and Electronic Document Management", "On Access to Public Information"; "On protection of information in information and telecommunication systems", "On electronic digital signature", "On protection of personal data"; Resolutions of the Cabinet of Ministers of 
Ukraine "On the Procedure for Exchange of Information between Urban and State Land Cadastres", "On Urban Cadastre", "On Approval of the Procedure for the Use of Computer Programs in Executive Bodies"; "On approval of the Procedure for the use of electronic digital signatures by public authorities, local governments, enterprises, institutions and organizations of state ownership", "On approval of the Rules for information protection in information, telecommunications and information and telecommunications systems"; DSTU 34.602-89 "Information technology. A set of standards for automated systems. Terms of reference for the creation of an automated system" [3].

Detailed requirements for the functioning of the system are determined during the development of the terms of reference and the AIS project, in particular: provisions for project development; spatial structure; functionality; discreteness; types of analysis and standard reports; development planning and strategies (ability to modernize, scale); electronic services.

The system should provide detailed information on:

1. Each subject of land relations, including relevant information about him, his property rights and property rights to land, as well as restrictions and encumbrances on these rights. Analytics by subject should include a list of land plots with areas of ownership and use in terms of rights to them, regions, purpose of land, etc.

2. Each land plot, including current information about it. Land analysis should include entities with areas of ownership and use and types of rights to them and should be presented in cartographic and tabular form.

3. Volumes of transactions and transactions with land for the selected period of time in different analytical sections - by regions, districts, settlements, forms of ownership, types of rights, types of transactions and other agreements, types of entities, category of land, purpose of land etc. For interactive analysis, there should be a user-friendly interface with the ability to filter and group data.

4. Availability and distribution of land plots at the selected time in different analytical sections - by regions, districts, settlements, forms of ownership, types 
of rights, residents and non-residents, organizational and legal forms of rights and other parameters, category of land, the purpose of land, the presence in state registers, types of economic activity, types of land.

5. Changes in the availability and distribution of land for the selected period. This section of the analysis should demonstrate the dynamics and pace of transformation of land and rights in the land reform process, provide answers to questions: how the state and use of land resources since the introduction of the agricultural market, how land is used by new owners, how land structure changes by category, target purpose, forms of ownership, how land is concentrated and consolidated, how land use changes over time through various forms of management, how urbanization and suburbanization "creeps", how other natural resources are ruined, how the share of non-productive land use grows, how the level of ecological stability of lands changes, etc. [4].

6. Access to retrospective (archival) data for each of the above sections. This information should show historical processes, creation of land plots, their division, unification, closure (archiving).

7. Analytical information on the identified problems in the data: inaccuracy, inconsistency, illogicality, exceeding the established indicators, etc.

8. Forecast of dynamics and spatial statistical modeling of phenomena and processes in the field of land relations, their economic, social and environmental aspects.

The relevance and reliability of information support of the system is achieved by taking into account the requirements for the composition and content of data, namely [5]:

- land cadastral:

- category;

- purpose;

- type of use;

- type of land;

- cadastral number; 
- catalog of coordinates of the land plot boundaries (type of storage);

- area (according to the document);

- NGOs;

- availability of easement $(+,-)$;

- presence of restrictions $(+,-)$;

- type (name) of restrictions;

- on civil law agreements:

- subjects of the agreement (types of subjects);

- subject of the agreement (plot, lease right, easement right);

- type of agreement ( (sale, gift, exchange, pledge, additional agreement (prolongation, amendments)\};

- $\quad$ area (unit of measure, type of display);

- administrative affiliation (location) of the object (subject) of the agreement (within the settlement, village council, OTG, district, region)

- administrative affiliation (registration) of the subjects of agreements;

- citizenship of the subject of the agreement, name;

- TIN, USREOU of the parties to the agreement;

- NACE of a legal entity;

- cost \{plots, units of area (ha, hectare, sq.m, shares)\};

- value of property law (term of property law, value of property law for the term);

- place of registration of the subject of the agreement (legal entity) Name Yu.O. ;

- type of legal entity (organizational and legal form of OJSC, PJSC, PJSC, LLC);

- encumbrances (rent, emphyteusis);

- about encumbrances;

- about legal entities (market participants); 
- about individuals (market participants);

- requirements for cases of writing information about objects, subjects, administrative territories, types, types of agreements and so on (nominal or in cases of content).

Architecturally, the AIS should include a database management system, front-end, back-end, web services and other subsystems. Preference is given to technologies of micro-service architecture, which should ensure its scalability, modularity, stability, versatility.

In this case, the determining factor for the development of AIS architecture is the choice of the latter model: the creation of a completely new or based on the National cadastral system.

The AIS database, in our opinion, should be centralized. Local databases are not created. The database must be integrated with spatial data and GIS modules. The spatial component of the database, if possible, gets rid of the implementation of spatial calculations (GIS calculations, transformations of coordinate systems, spatial sections, thermal maps, etc.), which are transferred to the software subsystems. This will unload the database and reduce the risks of its operation. Structurally, the database depends on the chosen architecture of the system and is based on the essence of the database of the State Land Cadastre, which are supplemented by system-specific objects and links [2].

The system should contain a number of interactive maps with the ability to display the base layers (including the cartographic basis) and sets of indicators for monitoring land and analysis of changes in their quantitative and qualitative status. AIS software must implement the following functional requirements for:

- land monitoring (three levels; market, analytics, forecast);

- geodetic basis;

- mathematical basis;

- cartographic basis;

- administration;

- technical protection of information; 
- boundaries of administrative division and its changes;

- data format (administrative, statistical spatial) for the system, for the client.

Among the requirements for the software is the creation of an electronic cabinet in accordance with the user's authority.

The System should provide for the possibility for the administrator to create and modify quick access panels, which accumulates the main sets of monitoring indicators and links to relevant reports and AIS resources.

The analytical subsystem should be based on the following principles [3]

- types of reports (static, dynamic);

- types of reports (in cartographic, graphical, schematic and tabular form);

- discreteness of sections (1 day, week, quarter, year, the whole period);

- reporting interface, which provides nesting and filtering.

It should also be possible to search for information on the System within the user's authority.

Conclusions and prospects. Based on the identified requirements for the software of the automated information system of land monitoring and soil quality control, the main directions of work on the terms of reference and the project of land monitoring, within which the automated system should be developed and operated, are determined.

The requirements for administration, ergonomics, infrastructure, ensuring the turnover of changes, geodetic and mathematical basis, etc. are also substantiated.

Ensuring the protection of information, including confidential information, is important, as the land monitoring system should contain not only information about the objects of monitoring, but also information about the subjects of land relations, whose rights should be guaranteed.

The need to use directories and classifiers is taken into account, in particular the classification of administrative-territorial entities of Ukraine taking into account administrative reform, economic activities, as well as integration with 
various state official registers as part of the national geospatial data infrastructure platform. 


\section{REFERENCES}

1. Dyshlyk O.P., Dorosh A.I., Tarnopolskyi A.V., Tarnopolskyi Ye.A. (2018). Infrastruktura heoprostorovykh danykh v Ukraini: stan ta metodolohichni problemy zakonodavchoho rehuliuvannia. Zemleustrii, kadastr i monitorynh zemel, 1, 33-43. doi: http://doi.org/10.31548/zemleustriy2018.01.004

2. Tarnopolskyi, A. V., Malashevskyi M.A., Tarnopolskyi Ye.A., Palamar A.Iu.. (2018). Deiaki aspekty pobudovy infrastruktury heoprostorovykh danykh. Molodyi vchenyi. 2, 54, 28-31.

3. Dorosh Y.M., Ibatullin Sh.I., Tarnopolskyi A.V., Dorosh O.S. (2020). Naukove obgruntuvannia udoskonalennia systemy derzhavnoho zemelnoho kadastru v Ukraini: teoretychni ta metodolohichni zasady. Zemleustrii, kadastr i $\begin{array}{llll}\text { monitorynh } & \text { zemel, } & 38-50 . & \text { doi: }\end{array}$ http://dx.doi.org/10.31548/zemleustriy2020.01.05

4. Dorosh Y. M., Ibatullin Sh. I., Avramchuk B. O., Kharytonenko R. A., Patiiuk O. O. (2019). Naukovo-pravovyi vysnovok - instrument rozviazannia problemnykh pytan $\mathrm{v}$ pravovii ploshchyni zemlevporiadnoi sfery. Zemleustrii, $\begin{array}{lllll}\text { kadastr i monitorynh zemel, 2, 86-92. DOI: } & \text { 2, }\end{array}$ http://dx.doi.org/10.31548/zemleustriy2019.02.09

5. Avramchuk B. O., Patiiuk O. O. (2019). Deiaki pytannia vidpovidnosti systemy koordynat USK-2000 zemelnomu zakonodavstvu. Zemleustrii, kadastr i monitorynh zemel, 1, 77-85. DOI: http://dx.doi.org/10.31548/zemleustriy2019.01.09

Ібатуллін Ш.І., Дорош О.С., Тарнопольський А.В.

ОСНОВНІ ВИМОГИ ДО РОЗРОБКИ ПРОГРАМНОГО ЗАБЕЗПЕЧЕННЯ АВТОМАТИЗОВАНОЇ СИСТЕМИ МОНІТОРИНГУ ЗЕМЕЛЬ

Виявлені основні вимоги до системи моніторингу земель, включаючи вимоги до ї̈ функціональності, інформачійного забезпечення, візуалізації 
просторової інформації, інтерактивних карт, структури бази даних, загальної архітектури, аналітичних критеріїв та інших видів забезпечення.

Визначено основні напрями моніторингу земель, в рамках яких має функціонувати автоматизована система, зокрема моніторинг цүивільноправових транзакиій у розрізі територій, форм власності, категорій земель; моніторинг динаміки цүін; моніторинг стану земель за їх кількісними та якісними характеристиками; оцінка та прогнозування трансформацї стану земель.

Обгрунтовані вимоги щуодо підсистем адміністрування, ергономіки, інфраструктури, забезпечення оборотності змін, геодезичної та математичної основи тощзо.

Наголошено на необхідності забезпечення захисту інформащуї, в тому числі конфіденційної, оскільки система моніторингу земель має містити не лище відомості про об'єкти моніторингу, а й відомості щзодо суб'єктів земельних відносин, права яких мають бути гарантовані.

Враховано необхідність використання довідників та класифікаторів, зокрема з класифікації адміністративно-територіальних утворень Украӥни, видів економічної діяльності, а також інтеграцію із різними державними офіиійними реєстрами у складі платформи нацуінальної інфраструктури геопросторових даних.

Ключові слова: програмне забезпечення, моніторинг земель, база даних, земельні ресурси, автоматизовані інформаційно- комунікативні системи, інфраструктура геопросторових даних, земельний кадастр.

Ибатуллин Ш.И., Дорош О.С., Тарнопольский А.В.

ОСНОВНЫЕ ТРЕБОВАНИЯ К РАЗРАБОТКЕ ПРОГРАММНОГО ОБЕСПЕЧЕНИЯ АВТОМАТИЗИРОВАННОЙ СИСТЕМЫ МОНИТОРИНГА ЗЕМЕЛЬ

Выявлены основные требования к системе мониторинга земель, включая требования кее функциональности, информационного обеспечения, 
визуализации пространственной информаџии, интерактивных карт, структуры базы данных, общей архитектуры, аналитических критериев и других видов обеспечения.

Определень основные направления мониторинга земель, в рамках которых должнна функиионировать автоматизированная система, в частности мониторинг гражданско-правовых сделок в разрезе территорий, форм собственности, категорий земель; мониторинг динамики иен; мониторинг состояния земель по их количественными и качественными характеристиками; оценка и прогнозирование трансформации состояния земель.

Обосновань требования по подсистемам администрирования, эргономики, инфраструктуры, обеспечения возвратности изменений, геодезической и математической основы и так далее.

Отмечена необходимость обеспечения защчиты информацчи, в том числе конфиденцииальной, поскольку система мониторинга земель должна содержать не только сведения об объектах мониторинга, но и сведения о субъектах земельных отношений, права которых должны быть гарантированьл.

Учтена необходимость использования справочников и классификаторов, в частности по классификации административнотерриториальных образований Украины, видов экономической деятельности, а также интеграцию с различными государственньми официиальныли реестрами в составе платформы национальной инфраструктуры геопространственных данных.

Ключевые слова: программное обеспечение, мониторинг земель, база данных, земельные ресурсы, автоматизированные информационно коммуникативные системы, инфраструктура геопространственных данных, земельный кадастр. 